\title{
PERBEDAAN KETINGGIAN AIR TERHADAP TINGKAT PERTUMBUHAN DAN KELANGSUNGAN HIDUP IKAN MASKOKI (Carassius auratus)
}

\author{
The Difference in Water Level from Growth and Survival Rates \\ in Goldfish (Carassius auratus)
}

\author{
Rangga Bayu Kusuma Haris ${ }^{1 *}$, Perdana Putra Kelana ${ }^{1}$, Muhammad Basri ${ }^{1}$, \\ Jefri Putri Nugraha ${ }^{2}$, dan Arumwati ${ }^{3}$ \\ 1) Politeknik Kelautan dan Perikanan Dumai \\ 2) Politeknik Kelautan dan Perikanan Sidoarjo \\ 3) Satuan Pengawasan SDKP Palembang, Indonesia \\ *Corresponding author: ranggabkh@gmail.com
}

\begin{abstract}
ABSTRAK
Penelitian ini bertujuan mengetahui pertumbuhan dan kelangsungan hidup benih ikan maskoki (Carassius auratus) dengan ketinggian air yang berbeda. Penelitian ini telah dilaksanakan pada Bulan Oktober 2018 sampai dengan November 2018 yang bertempat di Kampus C Fakultas Perikanan dan Kelautan Universitas PGRI Palembang yang beralamat Jalan Sakti Wiranata Kelurahan Srimulya Kecamatan Sematang Borang Palembang. Penelitian menggunakan Rancangan Acak Lengkap (RAL) dengan 4 taraf perlakuan dan 3 ulangan yaitu : A (Ketinggian air media $5 \mathrm{~cm} \mathrm{~B} \mathrm{(Ketinggian} \mathrm{air} \mathrm{media}$ $10 \mathrm{~cm}$ ), C (Ketinggian air media $15 \mathrm{~cm}$ ) dan D (Ketinggian air media $20 \mathrm{~cm}$ ). Hasil penelitian menunjukkan bahwa pertumbuhan berat rata-rata ikan maskoki (Carassius auratus) yang terbaik terdapat pada perlakuan B2 (ketinggian air $10 \mathrm{~cm}$ ) sebesar $0.77 \mathrm{gr}$ serta pertumbuhan panjang rata-rata ikan maskoki (Carassius auratus) sebesar $1.12 \mathrm{~cm}$ dan tingkat kelangsungan hidup ikan Maskoki (Carassius auratus) sebesar 96.67\%.
\end{abstract}

Kata Kunci: Ikan Maskoki (Carassius auratus), Ketinggian Air, Pertumbuhan, Kelangsungan Hidup

\begin{abstract}
This study aims to determine the growth and survival of goldfish (Carassius auratus) seeds with different water heights. This research has been carried out in October 2018 until November 2018 which is located at Campus C, Faculty of Fisheries and Marine, PGRI University, Palembang, located at Jalan Sakti Wiranata, Srimulya Village, Sematang Borang District, Palembang. The study used a Completely Randomized Design (CRD) with 4 treatment levels and 3 replications, namely: A (media water level $5 \mathrm{~cm} \mathrm{~B}$ (media water level $10 \mathrm{~cm}$ ), $C$ (media water level $15 \mathrm{~cm}$ ) and D (media water level $20 \mathrm{~cm}$ ). The results showed that the best average weight growth of goldfish (Carassius auratus) was found in treatment B2 (water level $10 \mathrm{~cm}$ ) of $0.77 \mathrm{gr}$ and the average length growth of goldfish (Carassius auratus) of $1.12 \mathrm{~cm}$ and the survival rate of fish Goldfish (Carassius auratus) by $96.67 \%$.
\end{abstract}

Keyword : Goldfish (Carassius auratus), Water Level, Growth, Survival Rate. 


\section{PENDAHULUAN}

Ikan maskoki merupakan komoditas perikanan yang potensial untuk dikembangkan, karena kelebihan yang di miliki ikan maskoki (Carassius auratus) mempunyai permintaan pasar yang terus meningkat, baik didalam negri maupun di luar negeri. Oleh karena itu ikan maskoki sebagai salah satu potensi sumberdaya perairan Indonesia dapat terus dikembangkan menjadi salah satu komoditas alternatif yang cukup penting dalam bidang budidaya perikanan (Septiara et al, 2012).

Menurut Nirmala et al (2011), Harga jual benih ikan maskoki ukuran $(5-7 \mathrm{~cm})$ ke pengepul bisa mencapai Rp2.000-5.000/ekor dan untuk indukannya yang belum matang gonad harganya dapat mencapai Rp75.000/pasang, sedangkan untuk indukan yang sudah matang gonad harganya dapat mencapai Rp250.000/pasang. Harga ikan maskoki (Carassius auratus) kualitas kontes biasa mencapai 10 juta/ekor, bahkan ikan maskoki yang menang dalam kontes harganya bisa mencapai 20 juta/ekor (Nadia et al, 2015).

Pada pemeliharaan benih tingkat ketinggian air sangat perlu diperhatikan karena pergerakan tubuh benih belum begitu cepat seperti ikan yang sudah dewasa maka dari itu ketinggian air yang semakin meningkat dapat mempercepat habisnya energi yang dilakukan oleh benih untuk mendapatkan makanan dan oksigen, maka energi yang ada didalam tubuh akan lebih banyak terpakai untuk pergerakan bukan pertumbuhan benih (Lesmana, 2004). Penelitian ini bertujuan untuk mengetahui pertumbuhan dan kelangsungan hidup benih ikan maskoki (Carassius auratus) dengan ketinggian air yang berbeda.

\section{METODE PENELITIAN}

Waktu dan Tempat

Penelitian ini telah dilaksanakan pada
Bulan Oktober 2018 sampai dengan
November 2018 yang bertempat di Kampus C Fakultas Perikanan dan Kelautan Universitas PGRI Palembang yang beralamat Jalan Sakti Wiranata Kelurahan Srimulya Kecamatan Sematang Borang Palembang.

\section{Metode Penelitian}

Penelitian menggunakan Rancangan Acak Lengkap (RAL) dengan 4 taraf perlakuan dan 3 ulangan yaitu :

Perlakuan $\mathrm{A}=$ Ketinggian air media $5 \mathrm{~cm}$

Perlakuan $\mathrm{B}=$ Ketinggian air media $10 \mathrm{~cm}$

Perlakuan $\mathrm{C}=$ Ketinggian air media $15 \mathrm{~cm}$

Perlakuan $\mathrm{D}=$ Ketinggian air media $20 \mathrm{~cm}$

Untuk mengetahui jumlah benih yang akan ditebar terlebih dahulu harus mengetahui berapa volume air yang ada dalam akuarium, untuk mengetahui volume air dapat menggunakan rumus (Fendy, 2012) yaitu:

$$
V=\frac{P \times L \times T \text { air }}{1000}
$$

Keterangan:

V: Volume air (L)

$\mathrm{P}$ : Panjang akuarium $(\mathrm{cm})$

L: Lebar akuarium $(\mathrm{cm})$

$\mathrm{T}$ air: Tinggi air $(\mathrm{cm})$

Dibagi 1000 untuk mengetahui jumlah liter, dimana $1 \mathrm{~cm}=1 / 1000$

\section{Parameter yang diamati}

Pertumbuhan Berat

Pertumbuhan Ikan maskoki dihitung berdasarkan selisih antara rataan bobot badan pada awal penelitian dengan rataan bobot badan pada akhir penelitian. Pertambahan berat ikan dihitung dengan rumus (Effendie, 1979):

$$
\mathrm{Wm}=\mathrm{Wt}-\mathrm{Wo}
$$

Keterangan :

$\mathrm{Wm}=$ Pertambahan berat rerata $(\mathrm{gr})$

$\mathrm{Wt}=$ Berat rata - rata ikan pada akhir penelitian (gr) 
$\mathrm{Wo}=$ Berat rata - rata ikan pada awal penelitian (gr)

\section{Laju pertumbuhan panjang}

Pertambahan panjang ikan yang dihitung dengan rumus (Effendie, 1979) sebagai berikut :

$$
\mathrm{Pm}=\mathrm{Pt}-\mathrm{Po}
$$

Keterangan :

$\mathrm{Pm}=$ Pertambahan panjang rerata $(\mathrm{cm})$

$\mathrm{Pt}=$ Panjang rata - rata ikan akhir penelitian $(\mathrm{cm})$

Po = Panjang rata - rata ikan pada awal penelitian $(\mathrm{cm})$

\section{Kelangsungan Hidup}

Untuk mengetahui tingkat kelangsungan hidup ikan selama penelitian dihitung pada akhir penelitian benih ikan mas koki dengan menggunakan rumus Effendie (1979) dalam Miswar et al, (2013) sebagai berikut :

Keterangan :

$$
S R=\frac{\mathrm{Nt}}{\mathrm{No}} \mathrm{X} 100 \%
$$

$\mathrm{SR}=$ Kelangsungan hidup $(\%)$

$\mathrm{Nt}=$ Jumlah Benih yang hidup akhir (ekor)
No = Jumlah Benih yang hidup pada awal (ekor)

\section{Kualitas Air}

Parameter kualitas air yang diamati adalah suhu, $\mathrm{pH}$, oksigen terlarut (DO), dan ammonia. Adapun cara kerja pengukuran kualitas air adalah

\section{Analisa Data}

Data hasil pengamatan yang diperoleh dianalisis secara statistika dengan menggunakan Analisa sidik ragam (ANSIRA)

\section{HASIL DAN PEMBAHASAN}

\section{Kelangsungan Hidup Ikan Maskoki (Carassius auratus)}

Berdasarkan Hasil pengamatan selama penelitian ketinggian air Ikan maskoki (Carassius auratus) diperoleh nilai tingkat kelangsungan hidup benih ikan Ikan maskoki (Carassius auratus) yang dapat dilihat pada Gambar 1.

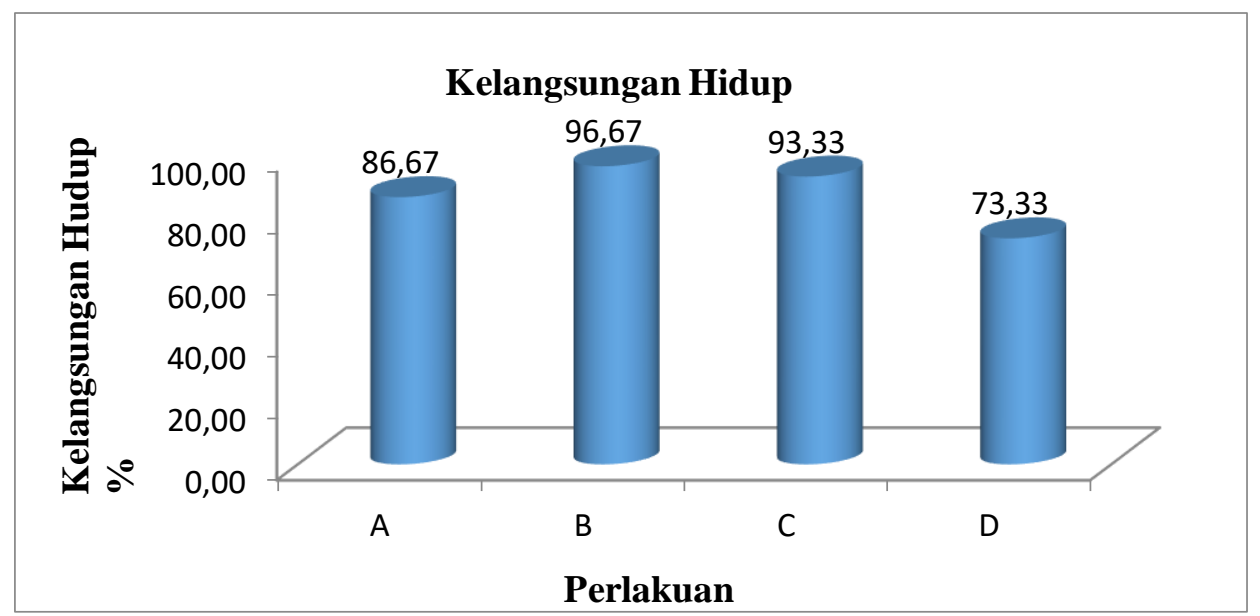

Gambar 1. Kelangsungan hidup benih ikan maskoki (Carassius auratus)

Rata-rata kelangsungan hidup benih Ikan maskoki (Carassius auratus) setiap perlakuan selama masa pemeliharaan disajikan pada gambar 1 menunjukkan bahwa persentase kelangsungan hidup benih Ikan maskoki (Carassius auratus) pada perlakuan 
ketinggian air $10 \mathrm{~cm}$ dengan nilai 96,67\% berbeda tidak nyata dari persentase kelangsungan hidup benih Ikan maskoki (Carassius auratus) pada perlakuan lainnya. Nilai rata-rata kelangsungan hidup terdapat kecenderungan bahwa semakin tingginya air media pemeliharaan maka tingkat kelangsungan hidup semakin menurun.

Nilai kelangsungan hidup yang terendah diperoleh pada perlakuan $\mathrm{D}$ yaitu $73,33 \%$ dengan ketinggian air $20 \mathrm{~cm}$. rendahnya tingkat kelangsungan hidup ikan maskoki pada perlakuan D kemungkinan juga dipengaruhi oleh perbedaan tingkat ketinggian air media pemeliharaan karena pada perlakuan ketinggian $20 \mathrm{~cm}$ media pemeliharaan yang digunakan ketinggian airnya cukup tinggi sehingga ikan maskoki membutuhkan energi yang cukup besar untuk melakukan gerak naik turun untuk mengambil oksigen ke permukaan. Semakin besar jarak yang ditempuh untuk mengambil oksigen ke permukaan maka semakin besar pula energi yang terpakai sehingga berpengaruh terhadap pertumbuhan dan kelangsungan hidupnya.

Hal ini sesuai dengan pendapat Witjaksono (2009), menyatakan bahwa ketinggian air yang tinggi menyebabkan jarak ke permukaan semakin besar sehingga mempengaruhi aktivitas ikan dalam mengambil oksigen dari udara. Semakin besar jarak yang ditempuh untuk mengambil oksigen ke permukaan maka semakin besar pula energi yang terpakai sehingga akan berpengaruh terhadap pertumbuhan dan kelangsungan hidup ikan.

Berdasarkan perhitungan kelangsungan hidup Ikan Maskoki (Carassius auratus) diperoleh hasil data Analisis ANSIRA ketinggian air media pemeliharaan terhadap kelangsungan hidup dapat dilihat pada Tabel 1.

Tabel 1. Hasil ANSIRA kelangsungan hidup ikan maskoki (Carassius auratus)

\begin{tabular}{lcccccc}
\hline \multicolumn{1}{c}{ SK } & DB & JK & KT & Fhitung & Ftabel \\
& & & & & $\mathbf{5 \%}$ & $\mathbf{1 \%}$ \\
\hline Perlakuan & 3 & 958.333 & 319.444 & $4.00^{\text {th }}$ & 4.07 & 7.59 \\
Galat & 8 & 638.889 & 79.861 & & & \\
Total & 11 & 1597.222 & & & & \\
\hline
\end{tabular}

Ket: ${ }^{\text {tn }}=10.21315$

$\begin{array}{ccc}\text { Data hasil analisis } & \text { ANSIRA } \\ \text { kelangsungan } & \text { hidup Ikan } & \text { Maskoki }\end{array}$ (Carassius auratus) pada tabel 1 menunjukan $F_{\text {hitung }}<\mathrm{F}_{\text {tabel }} 5 \%$ dimana $4.000<4.07$, yang artinya tidak berpengaruh nyata terhadap sintasan atau kelangsungan hidup ikan. Hal ini diduga karena daya dukung lingkungan masih memenuhi kebutuhan tiap-tiap populasi serta kebutuhan benih akan pakan terpenuhi. Nilai Koefisien Keragaman sebesar 10.21315 maka tidak perlu dilakukan uji lanjut.

Menurut Yuliati et al., (2003), Arianto et al (2019); Rosid et al (2019) menyatakan menurunnya kelangsungan hidup dapat di akibat karena peningkatan padat tebar sehingga menyebabkan ruang gerak ikan semakin sedikit yang berakibat pada ikan semakin berdesakan. Semakin tinggi populasi ikan dalam suatu media, kondisi kompetisi dalam memperoleh pakan dan ruang gerak tidak dapat ditoleransi lagi oleh ikan. Kondisi ini mengakibatkan tingkat kelangsungan hidup ikan menjadi terganggu, pertumbuhan ikan menurun dan variasi ukuran semakin tinggi. Menurut Ginting et al (2007), padat tebar dapat dikatakan optimal apabila ikan yang di tebar jumlah tinggi tetapi kompetisi dalam memperoleh pakan dan ruang gerak semakin masih dapat ditoleransi oleh ikan, sehingga menghasilkan tingkat 
kelangsungan hidup dan pertumbuhan ikan yang tinggi, serta variasi ukuran yang rendah

\section{Pertumbuhan}

Pertumbuhan Berat Mutlak Ikan Maskoki (Carassius auratus)
Berdasarkan hasil pengamatan terhadap peningkatan pertumbuhan berat ikan Maskoki (Carassius auratus) pada masing-masing perlakuan dapat dilihat pada Gambar 2.

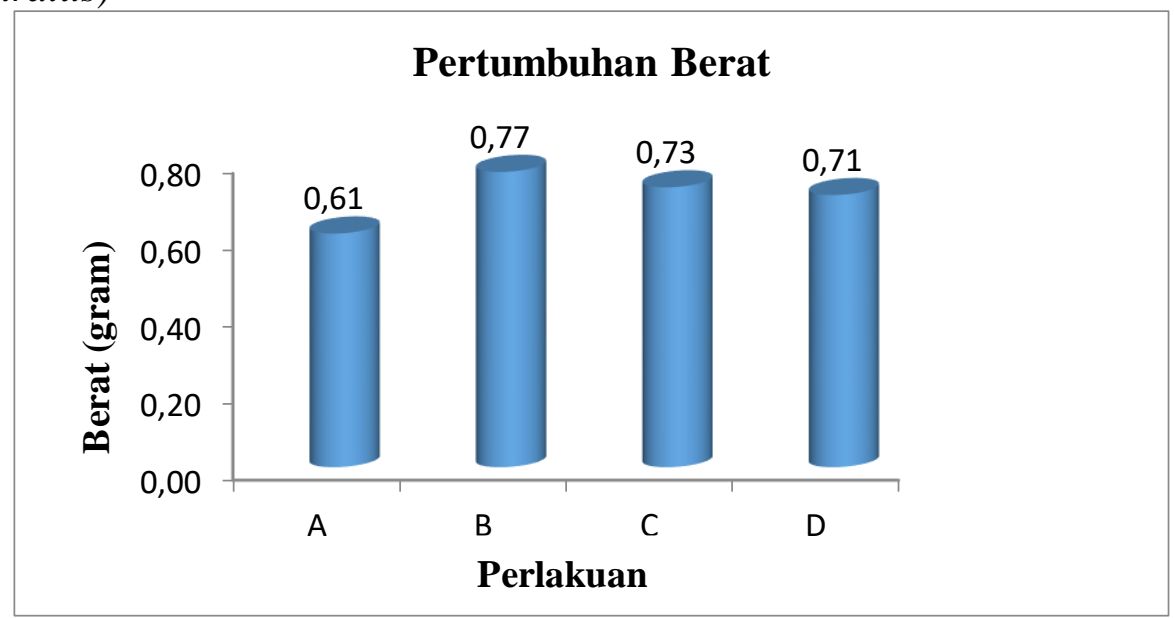

Gambar 2. Pertambahan berat ikan maskoki (Carassius auratus).

Berdasarkan hasil dari gambar 2 diatas menunjukkan nilai pertumbuhan berat tertinggi terdapat pada perlakuan B sebesar 0,77 gram, diikuti dengan perlakuan $\mathrm{C}$ sebesar 0,73 gram lalu perlakuan D sebesar 0,71 gram dan perlakuan A menghasilkan nilai yang terendah yaitu 0,61 gram.
Berdasarkan pengamatan pertumbuhan berat terhadap pertumbuhan ikan Maskoki (Carassius auratus) diperoleh hasil analisis sidik ragam (ANSIRA) terhadap pertumbuhan, kelangsungan hidup, dan ketinggian air Ikan Maskoki (Carassius auratus) dapat dilihat pada Tabel 2.

Tabel 2. Hasil ANSIRA pertumbuhan berat ikan maskoki (Carassius auratus)

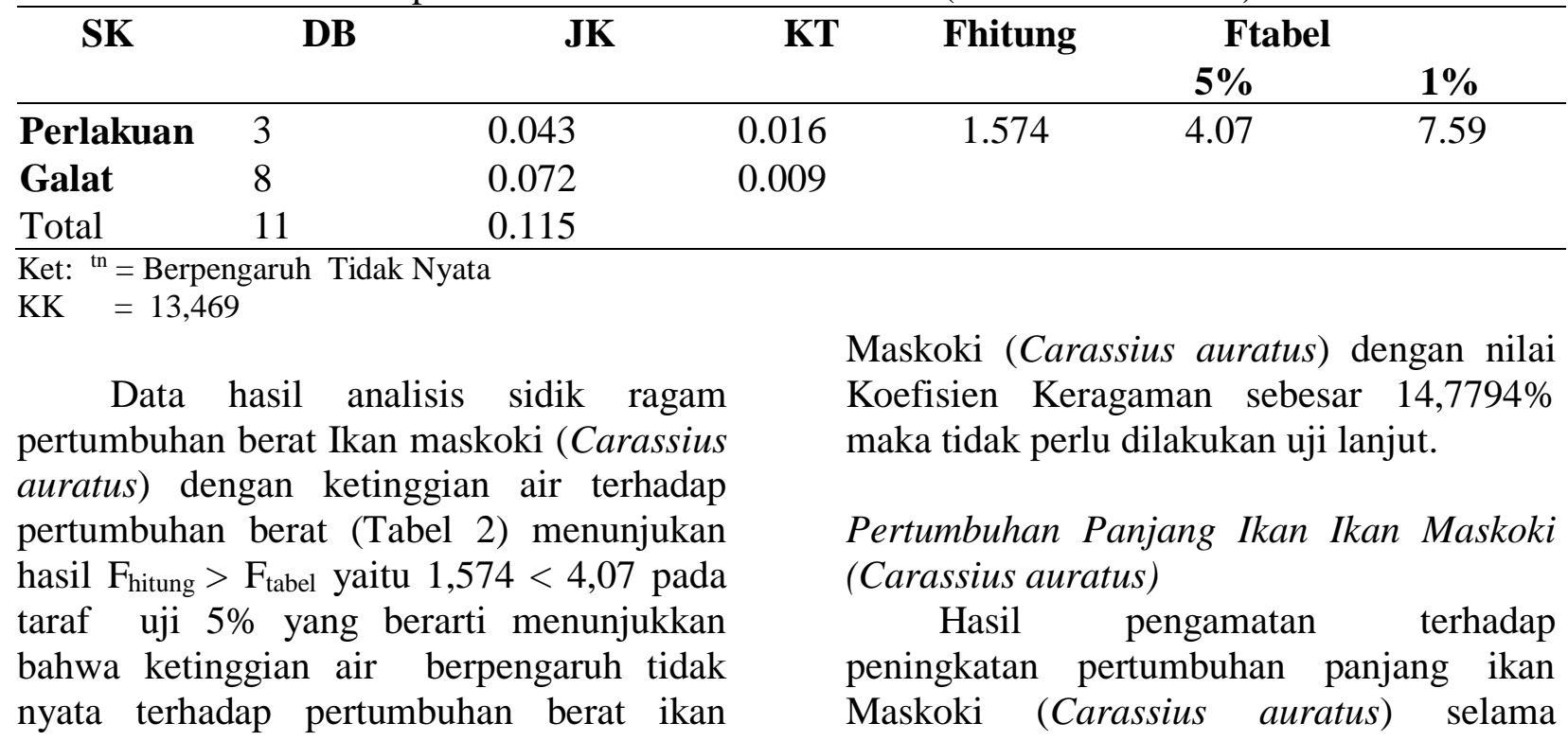


penelitian pada setiap perlakuan dapat dilihat pada Gambar 3.

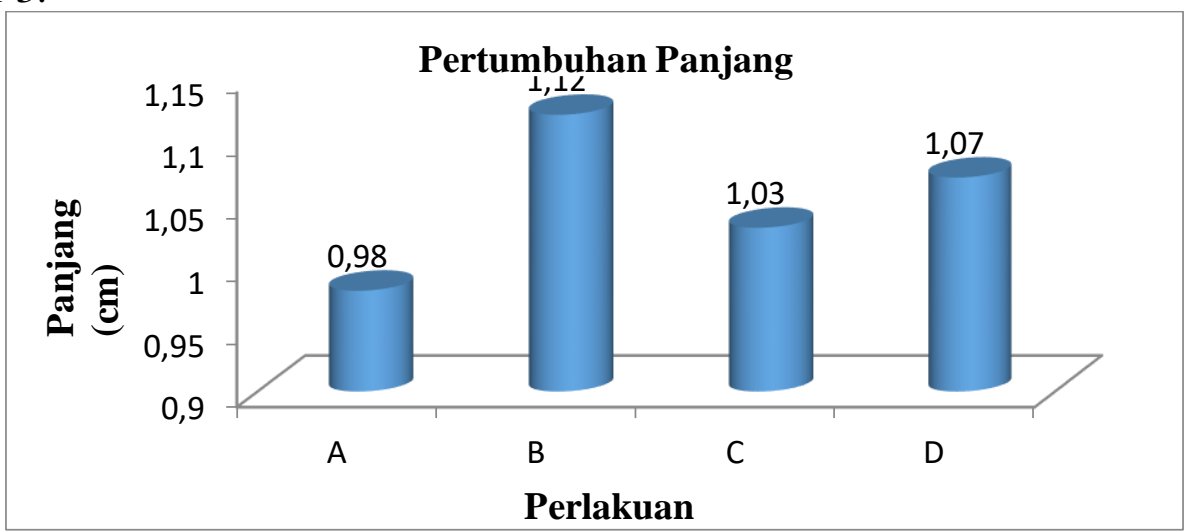

Gambar 3. Pertambahan panjang ikan maskoki (Carassius auratus)

Berdasarkan hasil dari gambar 3 diatas menunjukkan nilai pertumbuhan panjang tertinggi terdapat pada perlakuan B sebesar $1,12 \mathrm{~cm}$, diikuti dengan perlakuan D sebesar $1,07 \mathrm{~cm}$, lalu perlakuan $\mathrm{C}$ sebesar $1,03 \mathrm{~cm}$ dan perlakuan A menghasilkan hasil yang terendah yaitu $0,98 \mathrm{~cm}$. Berdasarkan pengamatan pertumbuhan panjang ikan Maskoki (Carassius auratus) diperoleh hasil Analisis ANSIRA ketinggian air terhadap pertumbuhan panjang ikan maskoki dapat dilihat pada Tabel 3 .

Tabel 3. Hasil ANSIRA Pertumbuhan Panjang Ikan Maskoki (Carassius auratus).

\begin{tabular}{lcccccr}
\hline \multicolumn{1}{c}{ SK } & DB & JK & KT & Fhitung & $\begin{array}{c}\text { Ftabel } \\
\mathbf{5 \%}\end{array}$ & $\mathbf{1 \%}$ \\
\hline Perlakuan & 3 & 0.029 & 0.010 & $5.314^{*}$ & 4.07 & 7.59 \\
Galat & 8 & 0.015 & 0.002 & & & \\
$\quad$ Total & $\mathbf{1 1}$ & $\mathbf{0 . 0 4 4}$ & & & & \\
\hline
\end{tabular}

Ket : ${ }^{*}=$ Berpengaruh Nyata

$\mathrm{KK}=4,0996$

Data hasil analisis ANSIRA pertumbuhan panjang Ikan maskoki (Carassius auratus) dengan ketinggian air pada Tabel 3 menunjukkan $F_{\text {hitung }}>\mathrm{F}_{\text {tabel }} 5 \%$ dimana $5.314>4,07$, yang artinya berpengaruh nyata dengan nilai Koefisien Keragaman sebesar 4,0996 maka dilakukan uji lanjut BNT yang dapat dilihat pada Tabel 4.

Tabel 4. Uji lanjut BNT pertumbuhan panjang ikan maskoki (Carassius auratus)

\begin{tabular}{ccc}
\hline Perlakuan & Rerata & Beda antar perlakuan \\
\hline A & 0.98 & $\mathrm{a}$ \\
C & 1.03 & $\mathrm{a}$ \\
$\mathrm{D}$ & 1.07 & $\mathrm{a}$ \\
$\mathrm{B}$ & 1.12 & $\mathrm{~b}$ \\
\hline
\end{tabular}

Keterangan: Angka yang diikuti oleh huruf yang sama menunjukkan beda yang tidak nyata pada taraf uji $5 \%$.

$\mathrm{BNT}_{0,05}=0,162$ 
Hasil penelitian pertumbuhan benih ikan maskoki (Carassius auratus) pada berbagai ketinggian air media pemeliharaan diperoleh pertambahan berat dan panjang terbaik pada perlakuan B sebesar 0,77 gr dan $1,12 \mathrm{~cm}$ diikuti Perlakuan $\mathrm{C}$ sebesar $0,73 \mathrm{gr}$ dan 1,03 cm, Perlakuan D sebesar 0,71 gr dan $0,17 \mathrm{~cm}$, Perlakuan A menghasilkan perrtumbuhan berat dan panjang terendah yaitu 0,61 gr dan $0,98 \mathrm{~cm}$. Pertumbuhan benih ikan maskoki (Carassius auratus) pada berbagai ketinggian air media pemeliharaan memberikan pertambahan berat dan panjang mutlak terbaik pada perlakuan B. Pertambahan berat rata-rata pada perlakuan B sebesar 0,77 gram dan panjang rata-rata 1,12 $\mathrm{cm}$.

Perlakuan B menunjukkan hasil pertumbuhan berat dan panjang tertinggi dibandingkan dengan perlakuan lainnya. Tingginya tingkat pertumbuhan ini dikarenakan ketinggian air benih ikan ikan maskoki (Carassius auratus) mendapatkan ruang gerak cukup yang mampu menunjang pertumbuhannya dan pakan yang diberikan dapat dimanfaatkan ikan untuk tumbuh. Pakan yang diberikan di makan kemudian dicerna dan diabsorbsi oleh tubuh digunakan untuk bergerak, adaptasi dan sisanya digunakan untuk pertumbuhan. Pertumbuhan akan terjadi jika jumlah makanan yang dimakan melebihi dari pada yang di butuhkan untuk mempertahankan hidupnya. Pada penelitian ini diduga pakan yang diberikan telah mampu menghasilkan respon pertumbuhan benih ikan maskoki (Carassius auratus) pada perlakuan B sebesar 0,77 gr dan panjang rata-rata $1,12 \mathrm{~cm}$.

Brett dalam Rahmi et al (2012), menyatakan bahwa untuk merangsang pertumbuhan optimum diperlukan jumlah dan mutu makanan yang tersedia dalam keaadaan cukup serta sesuai dengan kebutuhan. Menurut Effendie (2002), pertumbuhan dalam individu ikan ialah pertambahan jaringan akibat dari pembelahan sel secara mitosis, hal ini terjadi apabila ada kelebihan input energi dan asam amino (protein) berasal dari makanan, selanjutnya makanan akan digunakan oleh tubuh untuk metabolisme dasar, pergerakan, produksi organ seksual, perawatan bagianbagian tubuh atau menggantikan sel-sel yang sudah tidak terpakai. Dari segi pertumbuhan ikan, kelompok sel-sel suatu jaringan dalam bagian tubuh dapat digolongkan menjadi bagian yang dapat diperbaharui, bagian yang dapat berkembang dan bagian yang statis. Urat daging dan tulang pada ikan merupakan bagian terbesar dari tubuhnya, pertambahan sel-sel pada jaringan tersebut bertanggung jawab terhadap pertambahan massa ikan.

Perlakuan C $(15 \mathrm{~cm})$ dan Perlakuan D $(20 \mathrm{~cm})$ menunjukkan hasil pertambahan berat lebih rendah dibandingkan Perlakuan B. Hal ini diduga dengan penambahan ketinggian air mempengaruhi nafsu makan ikan yang berkurang terhadap pemberian pakan buatan. Ikan yang berukuran besar akan mempunyai ruang gerak yang lebih besar dibandingkan dengan ikan yang berukuran kecil, hal ini menyebabkan terjadinya perebutan tempat dan perebutan pakan. Energi yang berasal dari pakan selain dipergunakan untuk pertumbuhan juga dipergunakan untuk bergerak, adaptasi. Menurut Mardiyanto (2008), bahwa tidak semua makanan yang dimakan oleh ikan digunakan untuk pertumbuhan. Sebagian besar energi dari makanan digunakan untuk metabolisme basal (pemeliharaan), sisanya digunakan untuk aktivitas, pertumbuhan. Metabolisme merupakan semua reaksi kimia yang terjadi di dalam tubuh mahluk hidup, terdiri atas anabolisme dan katabolisme.

Perlakuan A $(5 \mathrm{~cm})$ menunjukan nilai yang terendah dibandingkan dengan perlakuan yang lainnya. Rendahnya tingkat pertumbuhan benih ini dikarenakan, ruang gerak terbatas sehingga terjadi perebutan wilayah antara ikan besar dan ikan kecil dan saat pemberian pakan pada benih ikan 
maskoki (Carassius auratus) terjadi perebutan makanan. Energi yang ada dalam tubuh ikan dipergunakan untuk bergerak dan persaingan dalam ruang gerak dan memperebutkan makanan sehingga pertumbuhan benih menjadi lambat. Pakan yang dimakan ikan tidak sepenuhnya dimanfaatkan untuk pertumbuhan. Selain itu sisa pakan yang terdapat dalam wadah menyebabkan penurunan nilai kualitas air berdampak terhadap pertumbuhan bahkan dapat menyebabkan kematian bagi ikan.

Pertumbuhan adalah perubahan ukuran baik panjang dan berat dalam satuan waktu. Pada penelitian ini pertumbuhan dievaluasi berdasarkan pertambahan panjang mutlak dan pertambahan bobot mutlak. Rata-rata pertambahan panjang mutlak dan pertambahan bobot mutlak selama penelitian dari hasil pengukuran yang dilakukan, selama satu Bulan masa pemeliharaan diperoleh pertambahan berat mutlak benih ikan maskoki (Carassius auratus) tertinggi yaitu pada perlakuan ketinggian air $10 \mathrm{~cm}$ yaitu sebesar 0,77 gram dan pertambahan berat mutlak terendah ditemukan pada perlakuan ketinggian air $5 \mathrm{~cm}$ yaitu sebesar 0,61 gr. Sedangkan untuk nilai pertambahan panjang mutlak tertinggi berada pada perlakuan ketinggian air $10 \mathrm{~cm}$ yaitu sebesar $1,12 \mathrm{~cm} . \mathrm{cm}$ dan terendah terdapat pada perlakuan ketinggian air $20 \mathrm{~cm}$ yaitu $1,07 \mathrm{~cm}$.

Hasil Analisa Sidik Ragam pada perhitungan pertambahan berat mutlak dan panjang mutlak pada penelitian ini menunjukkan bahwa pengaruh perlakuan tingkat ketinggian air media yang berbeda memberikan pengaruh berbeda nyata terhadap pertambahan bobot mutlak dan panjang mutlak. Hal ini menunjukkan bahwa pertambahan bobot mutlak dan panjang mutlak pada penelitian ini dipengaruhi oleh tingkat ketinggian air media budidaya. Adanya perbedaan yang nyata baik terhadap pertambahan bobot mutlak dan panjang mutlak pada penelitian ini diduga dipengaruhi oleh adanya jumlah benih ikan maskoki (Carassius auratus) akibat dari tingkat kelangsungan hidup yang berbeda antar perlakuan sehingga dengan ketinggian air yang tertentu dan pada jumlah individu yang tertentu pula benih ikan maskoki (Carassius auratus) mendapatkan ruang gerak yang kurang cukup dan tidak mampu menunjang pertumbuhannya.

Lovell (1989) menyatakan bahwa hubungan timbal-balik antara setiap individu ikan dengan ikan lainnya dipengaruhi oleh jumlah, ruang, ukuran dan spesies. Hubungan ini berpengaruh terhadap pertumbuhan ikan dan besarnya interaksi yang terjadi antara setiap individu ikan dan mempengaruhi kemampuan ikan untuk memperoleh makanan. Selanjutnya dikatakan bahwa awal dari hasil persaingan ruang dan pakan, ikan akan mengembangkan pola tingkah laku yang bermacam-macam, meliputi pertahanan dan dominansi.

\section{Kualitas Air}

Pengamatan kualitas air yang dilakukan selama penelitian meliputi $\mathrm{pH}$, suhu, oksigen (DO), dan Amonia (NH3). Secara keseluruhan kisaran parameter kualitas air tersebut masih berada dalam kisaran normal dan layak bagi kehidupan ikan. Hasil kisaran pengamatan kualitas air selama penelitian pada Tabel 5 . 
Tabel 5. Parameter kualitas air selama penelitian

\begin{tabular}{lcccc}
\hline \multicolumn{1}{c}{ Parameter } & \multicolumn{3}{c}{ Perlakuan } \\
\cline { 2 - 5 } & P1 & P2 & P3 & P4 \\
\hline $\mathrm{pH}$ & 7,3 & 7,0 & 7,4 & 7,4 \\
$\mathrm{DO}(\mathrm{mg} / \mathrm{L})$ & 4,66 & 4,76 & 4,13 & 4,10 \\
Suhu $\left({ }^{\circ} \mathrm{C}\right)$ & 26 & 26 & 26 & 26 \\
Amonia $(\mathrm{mg} / \mathrm{L})$ & 1,09 & 1,08 & 1,11 & 1,14 \\
\hline
\end{tabular}

Berdasarkan pengamatan kualitas air yang dilakukan selama penelitian meliputi $\mathrm{pH}$, suhu, oksigen (DO), dan amoniak $\left(\mathrm{NH}_{3}\right)$.

$\mathrm{pH}$

Pengamatan $\mathrm{pH}$ air selama penelitian Ikan Maskoki (Carassius auratus) berada pada lingkungan yang layak untuk tumbuh dan berkembang. Nilai $\mathrm{pH}$ air berkisar antara 7,0 sampai dengan 7,4. Nilai $\mathrm{pH}$ yang dianggap ideal untuk menumbuh perkembangan maskoki (Carassius auratus) berkisar dari 7-8 (Ginting et al, 2013). Meskipun demikian, bahwa maskoki (Carassius auratus) masih dapat mentolelir nilai $\mathrm{pH}$ lebih rendah atau lebih tinggi dari kisaran tersebut. Walaupun maskoki mempunyai toleransi lebar terhadap berbagai nilai $\mathrm{pH}$. Akan tetapi, seperti diketahui ikan maskoki (Carassius auratus) termasuk dalam kelompok ikan mas pada umumnya, mereka tidak akan bisa bertahan pada $\mathrm{pH}$ dibawah 5 atau diatas 10. Untuk itu, dalam melakukan pengelolaan air perlu memperhatikan kadar pH-nya agar tidak sampai membahayakan kehidupan maskoki (Carassius auratus) (Beauty et al, 2012).

Menurut Wihardi et al (2014), menyatakan bahwa $\mathrm{pH}$ yang bersifat asam mengakibatkan terganggunya proses metabolisme ikan, selera makan ikan akan berkurang dan ikan mudah terserang penyakit, serta $\mathrm{pH}$ yang bersifat basah menyebabkan meningkatnya kandungan amonia sehingga dapat mengganggu kehidupan ikan dengan tanda-tanda gerakan tidak teratur, tutup insang bergerak aktif, berenang dengan cepat di permukaan air dan berpengaruh terhadap nafsu makan ikan.

Suhu

Suhu air selama penelitian ikan maskoki (Carassius auratus) pada setiap perlakuan berkisar antara $26^{\circ} \mathrm{C}$. Suhu dapat yang mempengaruhi laju metabolisme yang dapat menghambat pertumbuhan dan perkembangan gonad serta menurunkan daya tahan tubuh ikan, sedangkan suhu air yang terlalu tinggi dapat menyebabkan organisme menjadi stress dan suhu juga sangat berperan dalam mengendalikan kondisi ekosistem perairan (Miswar et al, 2013). Menurut Kordi (2000) dalam Ramadhan et al (2020); perubahan suhu dipengaruhi oleh parameter lainnya, diantaranya musim, cuaca, waktu pengukuran, kedalaman air serta kecerahan suatu perairan. Lebih lanjut Effendi (2003), menambahkan bahwa suhu dipengaruhi oleh musim, lintang (latitude), ketinggian dari permukaan laut (atlitude), waktu dalam hari, sirkulasi udara, peniupan awan, dan aliran kedalaman air. Organisme akuatik memiliki kisaran (batas atas dan bawah) suhu yang disukai bagi pertumbuhan. Menurut Beauty et al, (2012); suhu air yang ideal bagi pertumbuhan ikan maskoki (Carassius auratus) yaitu $12^{\circ} \mathrm{C}-30^{\circ} \mathrm{C}$, sedangkan di daerah tropis ikan maskoki (Carassius auratus) lebih produktif karena lingkungan lebih hangat yaitu $23^{\circ} \mathrm{C}-29^{\circ} \mathrm{C}$. Fluktuasi perubahan suhu direkomendasikan tidak lebih dari $5^{0} \mathrm{C}$, terutama dalam proses pergantian air atau proses transportasi. Fluktuasi suhu diatas $5^{0} \mathrm{C}$ akan sangat 
membahayakan ikan maskoki (Carassius auratus).

Suhu juga merupakan satu diantara beberapa parameter yang mentukan keberhasilan budidaya ikan maskoki (Carassius auratus), hal ini disebakan karena ikan maskoki (Carassius auratus) merupakan hewan berdarah dingin. Hewan berdarah dingin adalah hewan yang suhu tubuhnya dipengaruhi oleh suhu lingkungan. Suhu yang tinggi juga dapat menyebabkan meningkatnya proses metabolisme ikan maskoki (Carassius auratus) yang meningkatkan intensitas pembuangan kotoran sehingga kandungan oksigen menurun (Ginting, 2014) .

\section{Oksigen Terlarut}

Kandungan oksigen terlarut selama penelitian berkisar antara 4,10 - 4,76 mg/l, berdasarkan pengukuran untuk kandungan oksigen terlarut termasuk dalam toleransi untuk ikan maskoki. Menurut Miswar et al (2013); Hafiz et al (2020) menyatakan bahwa oksigen dibutuhkan untuk menjaga kondisi ikan agar tetap sehat dan terhindar dari stress. Kandungan oksigen yang terlarut untuk pemeliharaan ikan maskoki (Carassius auratus) berkisar $3-5 \mathrm{mg} / \mathrm{L}$.

Penurunan kualitas air dapat menyebabkan pertumbuhan ikan terganggu. Selama masa pemeliharaan penurunan kualitas air dapat dicegah dengan melakukan pembersihan bahan hasil metabolisme dan sisa pakan melalui penyifonan (Miswar et al, 2013). Selain itu juga dilakukan pergantian air sebesar 100\% setiap harinya. Sedangkan kandungan oksigen air disuplai dengan menggunakan blower sehingga dapat mencegah adanya penurunan kandungan oksigen air.

\section{Amonia}

Nilai amonia selama penelitian menunjukkan nilai yang sudah cukup optimal untuk pertumbuhan ikan maskoki (Carassius auratus) dimana nilai amonia pada masingmasing perlakuan berkisar antara 1,08 - 1,44. Menurut Miswar et al (2013), kandungan amoniak untuk pemeliharaan ikan maskoki (Carassius auratus) berkisar $<1 \mathrm{ppm}$. Hasil pengukuran kadar amonia menunjukkan nilai amonia pada setiap perlakuan masih dalam kisaran yang cukup optimal untuk kelangsungan hidup ikan maskoki (Carassius auratus).

Masih cukup optimalnya nilai amonia hal tersebut dikarenakan kondisi air selalu dijaga dengan melakukan pembersihan akuarium dan juga pergantian air setiap harinya. Dimana menurut Wihardi et al (2014), menyatakan bahwa sumber amonia didalam air dapat dipengaruhi oleh sisa-sisa pakan dan kotoran ikan. Amoniak (NH3) berasal dari perombakan bahan-bahan organik dan pengeluaran hasil metabolisme ikan melalui ginjal dan jaringan insang, amoniak juga dapat terbentuk dari hasil proses dekomposisi protein yang berasal dari sisa pakan yang merupakan racun bagi ikan sekalipun kosentrasinya sangat rendah (Lesmana, 2004). Walaupun selama penelitian terdapat sisa-sisa pakan dan kotoran ikan yang mengendap didasar air akan tetepi jumlahnya tidak terlalu banyak dan dapat diatasi langsung dengan cara penyiponan air yang rutin sehingga tidak menyebabkan kadar amonia yang terlalu tinggi.

\section{KESIMPULAN DAN SARAN Kesimpulan}

Berdasarkan hasil penelitian yang telah dilakukan, dapat disimpulkan bahwa : Pertumbuhan berat rata-rata ikan maskoki (Carassius auratus) yang terbaik terdapat pada perlakuan B (ketinggian air $10 \mathrm{~cm}$ ) sebesar 0,77 gram serta pertumbuhan panjang rata-rata ikan maskoki (Carassius auratus) terbaik sebesar $1,12 \mathrm{~cm}$. Tingkat Kelangsungan hidup ikan Maskoki (Carassius auratus) selama penelitian 
menunjukkan nilai yang terbaik terdapat pada perlakuan B yaitu $96,67 \%$ dengan ketinggian airnya $10 \mathrm{~cm}$.

\section{Saran}

Dari hasil penelitian kelangsungan hidup dan pertumbuhan ikan maskoki (Carassius auratus) pada ketinggian air media budidaya perlu diadakan penelitian lanjutan dengan meningkatkan ketinggian air sehingga dapat diketahui sampai dimana kisaran pertumbuhan ikan sampai menuju adanya penurunan pertumbuhan. Selain itu juga, perlu dilakukan penelitian mengenai perlakuan padat tebar optimal.

\section{DAFTAR PUSTAKA}

Arianto, D, Harris, H., Yusanti, I.A., dan Arumwati, A. 2019. Padat Penebaran Berbeda Terhadap Kelangsungan Hidup, Fcr Dan Pertumbuhan Ikan Bawal Air Tawar (Colossoma macropomum) Pada Pemeliharaan Di Waring. Jurnal Ilmu-ilmu Perikanan dan Budidaya Perairan. Vol.14(2). Hlm : 14-20.

Beauty, G. Yustiati, A. dan Grandiosa, R. 2012. Pengaruh Dosis Mikroorganisme Probiotik pada Media Pemeliharaan terhadap Kelangsungan Hidup dan Pertumbuhan Benih Maskoki (Carassius auratus) dengan Padat Tebar Penebaran Berbeda. Jurnal Perikanan dan Kelautan. Universitas Padjajaran. 3(3) : 1-6

Effendie, M. I. 2002. Biologi Perikanan. Yogyakarta : Yayasan Pustaka Nusantara. 163.

Effendi, H. 2003. Telaah Kualitas Air : Bagi Pengelolaan Sumber Daya dan Lingkungan Perairan. Kanasius. Yogyakarta.

Effendie, M.I. 1979. Metode Biologi Perikanan. Yayasan Pustaka Nusantara. Bogor.
Ginting, A. Usman, A. dan Dalimunthe, A. 2013. Pengaruh Padat Tebar terhadap Kelangsungan Hidup dan Laju Pertumbuhan Ikan Maskoki (Carassius auratus) yang dipelihara dengan Sistem Resirkulasi. Jurnal Aquacoastmarine. Universitas Sumatera Utara. 5(4) : 104-113.

Hafiz, M., Mutiara, D., Haris, R.B.K., Pramesthy, T.D., Mulyani, R., dan Arumwati. A. 2020. Analisis Fotoperiode Terhadap Kecerahan Warna, Pertumbuhan Dan Kelangsungan Hidup Ikan Komet (Carassius auratus). Jurnal Ilmu-ilmu Perikanan dan Budidaya Perairan. Vol.15(1) : 1-9. DOI: http://dx.doi.org/10.31851/jipbp.v15i1 .4287.

Hepher B. And Y Pruginin. 1981. Comercial Fish Farming : With Special Reference to fish Culture in Israel. John Wiley \& Sons. New York.

Huet M. 1972. Text Book of Fish Culture Cultivation. Fishing New Books Ltd, London.

Lesmana, DS. 2004. Kualitas Air untuk Ikan Hias Air Tawar. Jakarta ; PT. Penebar Swadaya.

Lovell T. 1989. Nutrition and Feeding of Fish. New York: Van Nostrand Reinhold.

Mardiyanto, 2005. Pertumbuhan dan Kelangsungan Hidup Ikan Maskoki dengan Kepadatan Berbeda pada Teknologi Pendederan dalam Sistem Resirkulasi. Skripsi. Fakultas Perikanan dan Ilmu Kelautan. Institut Pertanian Bogor. Bogor. 39 hlm.

Miswar, E. Syukran, dan Anggraini, S.H. 2013. Pengaruh Perbedaan Wadah terhadap Keberhasilan Pembenihan Ikan Maskoki (Carassius aurstus). Univeristas Syiah Kuala. 1(1) : 8 -10.

Nadia, E. M. Elfrida. dan Deswati, L. 2015. Pemberian Korteks Otak Sapi pada 
Pakan Nauplius Artemia untuk Meningkatkan Kelangsungan Hidup dan Pertumbuhan Larva Ikan Maskoki (Carassius aurstus). Jurnal Budidaya Perikanan. Univesitas Bung Hatta. 6 (1) : 1-12.

Nirmala, K. Armansyah, R. dan Priyadi, A. 2011. Kinerja Pertumbuhan Benih Ikan Maskoki Mutiara (Carassius auratus) pada Air Media Bersalinitas 3 ppt dengan Lama Paparan Medan Listrik yang berbeda. Jurnal Akuakultur Indonesia. Institut Pertanian Bogor. 10 (2) : 165-173.

Rahmi, A, Muslim dan Zuhriyani, H 2012. Pemeliharaan Ikan maskoki (Carassius auratus) Dengan Pemberian Pakan Yang Berbeda. Jurnal Fisheries 1(1) : 1-10.

Ramadhan, R., dan Yusanti, I.A. 2020. Studi Parameter Studi Kadar Nitrat Dan Fosfat Perairan Rawa Banjiran Desa Sedang Kecamatan Suak Tapeh Kabupaten Banyuasin. Jurnal Ilmuilmu Perikanan dan Budidaya Perairan. Vol 15(1) : 37-41. DOI: http://dx.doi.org/10.31851/jipbp.v15i1 .4407.

Rosid, M.M., Yusanti, I.A., dan Mutiara, D. 2019. Tingkat Pertumbuhan dan Kecerahan Warna Ikan Komet (Carassius auratus) Dengan Penambahan Konsentrasi Tepung Spirulina sp Pada Pakan. Jurnal Ilmuilmu Perikanan dan Budidaya Perairan. 14 (1) : 37-45.

Septiara, I. Maulina, I. Buwono, I.D. 2012. Analisis Pemasaran Ikan Maskoki di Kelompok Pembudidaya Ikan Kalapa Ciung Kecamatan Cimalaka Kabupaten Sumedang. Jurnal Perikanan dan Kelautan. Universitas Padjajaran. 3(3) : 69-73

Wihardi. Y., Yusanti, I.A., dan Haris, R.B.K. 2014. Feminisasi pada Ikan Mas (Cyprinus carpio) dengan Perendaman
Ekstrak Daun-Tangkai Buah Terung Cepoka (Solanum torvum) pada Lama Waktu Perendaman Berbeda. Jurnal Ilmu-ilmu Perikanan dan Budidaya Perairan. 9(1) : $23-28$.

Witjaksono, A. 2009. Kinerja Produksi pendederan lele sangkuriang (Clarias $S p)$ melalui penerapan teknologi ketinggian media air $15 \mathrm{~cm}, 20 \mathrm{~cm}, 25$ $\mathrm{cm}$, dan $30 \mathrm{~cm}$. Skripsi. Fakultas Perikanan dan Ilmu Kelautan. Institut Pertanian Bogor. Bogor.

Yuliati, P., Kadarini, T., Rusmaedi dan Subandiyah, S. 2003. Pengaruh Padat Penebaran Terhadap Pertumbuhan dan Sintasan Dederan Ikan Nila Gift (Oreochromis niloticus) Di Kolam. Jurnal Iktiologi Indonesia. 3(2):63-66. 